\title{
Efektivitas Sanitizer Komersial Berbasiskan Asam Perasetat terhadap Biofilm Bacillus cereus
}

\author{
Effectiveness of Peracetic Acid-based Commercial Sanitizers on Bacillus cereus Biofilms
}

\author{
N. Eliza ${ }^{1}$, R. Dewanti-Hariyadi ${ }^{2,3 *}$, \& S. Nurjanah ${ }^{2,3}$ \\ ${ }^{1}$ Program Studi Ilmu Pangan, Departemen Ilmu dan Tenologi Pangan. Fakultas Teknologi Pertanian, \\ IPB University \\ ${ }^{2}$ Departemen Ilmu dan Teknologi Pangan, Fakultas Teknologi Pertanian, IPB University \\ ${ }^{3}$ Southeast Asean Food and Agricultural Science and Technology (SEAFAST) Center, IPB University \\ Kampus IPB Darmaga Bogor, 16680, Indonesia \\ *Corresponding author: ratihde@apps.ipb.ac.id \\ (Received 10-07-2021; Revised 08-09-2021; Accepted 15-10-2021)
}

\begin{abstract}
Bacillus cereus is known to have the ability to adhere and form biofilms on the surface of stainless steel that causes problems in the food industries. Bacterial biofilms generally can increase resistance to sanitizer treatment. This study aimed to evaluate the ability of peracetic acid-based commercial sanitizer to inactivate B. cereus biofilm on stainless steel (SS) surfaces. Biofilm of B. cereus ATCC 10876 was developed on SS surfaces and treated with 7 commercial peracetic acid-based sanitizers at their recommended dosages. Two sanitizers, i.e. B (peracetic acid and QAC) and F (peracetic acid and acidified water) showing the ability to inactivate $B$. cereus on solid media at concentration of 200,400 , and 800 ppm were further tested on biofilms with contact times of 1,3 , and 5 minutes. The 48 hours biofilms B. cereus contained 2.78-3.78 CFU/cm2. Both sanitizers $B$ and $F$ had significant effects in inactivating $B$. cereus biofilm. In general, sanitizer B could reduce more biofilm bacteria at any contact time than sanitizer F. Use of 200 ppm of sanitizer B or F 5 minutes could inactivate $3.04 \log$ CFU/cm 2 and $2.68 \mathrm{log}$ $\mathrm{CFU} / \mathrm{cm} 2$ biofilm, respectively. Exposure of $B$. cereus biofilm to peracetic acid-based sanitizer resulted in the damage of the extracellular matrix of the biofilms. This study showed that commercial sanitizers containing peracetic acid and quaternary ammonium compounds were effective in inactivating $B$. cereus biofilms.
\end{abstract}

Keywords: Bacillus cereus, biofilm formation, peracetic acid, stainless steel surface, quaternary ammonium compound

\begin{abstract}
ABSTRAK
Bacillus cereus diketahui memiliki kemampuan menempel dan membentuk biofilm pada permukaan stainless steel sehingga berpotensi menyebabkan masalah pada industri pangan. Biofilm bakteri dapat meningkatkan resistensi terhadap perlakuan sanitizer. Penelitian ini bertujuan untuk mengevaluasi kemampuan sanitizer komersial berbasis asam perasetat untuk menginaktivasi biofilm $B$. cereus pada permukaan stainless steel (SS). Biofilm B. cereus ATCC 10876 dibentuk pada permukaan SS dan diberi perlakuan dengan 7 sanitizer berbasis asam perasetat komersial pada dosis yang direkomendasikan. Dua sanitizer yaitu B (asam perasetat dan QAC) dan F (asam perasetat dan air yang diasamkan) yang menunjukkan kemampuan inaktivasi pada media padat pada konsentrasi 200, 400, dan 800 ppm diuji lebih lanjut pada biofilm dengan waktu kontak 1, 3, dan 5 menit. Biofilm $B$. cereus berusia 48 jam 2.783.78 CFU/cm2. Sanitizer B dan F memiliki efek signifikan dalam menginaktivasi biofilm B. cereus. Secara umum, sanitizer B dapat mereduksi lebih banyak bakteri biofilm pada setiap waktu kontak dibandingkan sanitizer F. Penggunaan 200 ppm sanitizer B dan F selama 5 menit dapat menginaktivasi biofilm sebesar 3.04 log CFU/cm2 dan 2.68 log CFU/cm2. Pemaparan sanitizer menyebabkan kerusakan pada matriks ekstraselular biofilm. Penelitian ini menunjukkan bahwa sanitizer komersial yang mengandung asam perasetat dan senyawa ammonia kuaterner efektif dalam menginaktivasi biofilm $B$. cereus.
\end{abstract}

Kata kunci: asam perasetat, Bacillus cereus, pembentukan biofilm, permukaan stainless steel, senyawa ammonia kuaterner 


\section{PENDAHULUAN}

B. cereus merupakan bakteri Gram positif dan pembentuk spora yang banyak tersebar di alam sehingga memiliki kecenderungan tinggi untuk mengontaminasi bahan pangan. B. cereus umumnya mengontaminasi produk susu dan turunannya, sehingga menyebabkan dampak negatif berupa penurunan kualitas organoleptik (Kumari dan Sarkar 2016). Selain itu, B. cereus juga diketahui tumbuh pada substrat dengan kandungan glukosa tinggi seperti nasi (Chang et al. 2011), serta produk kering seperti rempahrempah (Fogele et al. 2017).

B. cereus memiliki kemampuan melekat yang sangat kuat pada berbagai jenis permukaan, termasuk permukaan stainless steel. B. cereus yang melekat dapat membentuk biofilm pada permukaan stainless steel dan menyebabkan masalah pada industri pangan (Peng et al. 2002). Biofilm adalah agregat mikroba yang membentuk suatu matriks yang disebut dengan extracellular polymeric substances (EPS). B. subtilis dan B. cereus dilaporkan mampu bersporulasi pada kondisi kompleks seperti biofilm (Branda et al. 2001; Wijman et al. 2007). Kemampuan tersebut cenderung meningkatkan ketahanan panas dan masa dorman spora $B$. cereus (Voort dan Abee 2012). Pada industri pengolahan susu, misalnya, spora $B$. cereus dapat bergerminasi ketika dikenai suhu tinggi dan menyebabkan terbentuknya biofilm pada permukaan SS. Biofilm B. cereus dapat berkembang pada sistem penyimpanan dan perpipaan yang terisi sebagian, karena biofilm $B$. cereus cenderung ditemukan lebih tebal dan tinggi pada air-liquid interface jika dibandingkan pada submerged system (Wijman et al. 2007). Setelah biofilm terbentuk, endospora dan sel vegetatif akan terperangkap dalam struktur biofilm dan menjadikannya resisten terhadap senyawa sanitizer (Ryu dan Beuchat 2005).

Beberapa studi mengenai inaktivasi biofilm pada permukaan telah dilaporkan, misalnya pada biofilm Bacillus cereus, Salmonella enterica Thypimurium, Listeria monocytogenes, dan Escherichia coli dengan klorin, klorin dioksida, asam perasetat, acidified sodium chloride, dan senyawa ammonia kuaterner (Ryu dan Beuchat 2005; Lee et al. 2017; Visvalingam dan Holley 2018). Menurut Chino et al. (2017), asam perasetat merupakan disinfektan yang efektif dalam menginaktivasi biofilm Staphylococcus aureus dan Pseudomonas aeruginosa. Mekanisme kerja asam perasetat belum banyak diketahui, akan tetapi diyakini memiliki fungsi serupa dengan oksidator lain yang mampu mendenaturasi protein, mengganggu permeabilitas dinding sel, dan mengoksidasi ikatan sufihidril dan belerang dalam protein (CDC 2016). Sementara itu, senyawa ammonia kuaterner (quat) sering diaplikasikan karena tidak korosif dan memiliki kestabilan yang baik di dalam larutan. Senyawa ammonia kuaterner juga memiliki efektivitas dalam menurunkan biofilm B. cereus (Kim et al. 2019).

Penggunaan kombinasi metode maupun senyawa dalam proses sanitasi telah banyak diterapkan oleh industri pangan. Salah satu tujuan pengkombinasian tersebut adalah untuk meningkatkan efektivitas dan efisiensi proses sanitasi. Bang et al. (2017) dan Huang et al. (2019) menunjukkan bahwa penggunaan kombinasi metode sanitasi dalam menginaktivasi biofilm terbukti memberikan efek yang sinergis dan mampu mereduksi lebih banyak biofilm. Tujuan dari penelitian ini adalah untuk mengetahui efektivitas sanitizer komersial yang mengandung asam perasetat dalam menginaktivasi biofilm $B$. cereus berdasarkan konsentrasi penggunaan dan waktu kontak paparan.

\section{MATERI DAN METODE}

Bakteri uji yang digunakan dalam penelitian ini adalah Bacillus cereus ATCC 10876 yang diperoleh dari Institut Pertanian Bogor Culture Collection (IPBCC). Selain itu digunakan brain heart infusion (BHI) broth (Merck) sebagai media penyegaran, media 1/10 tryptic soy broth (TSB, Oxoid Ltd, UK), tryptic soy agar (TSA, Oxoid Ltd, UK) sebagai media pertumbuhan, letheen broth (Scharlau) sebagai neutralizer, serta pewarna kristal violet ammonium-oksalat, lugol iodin, ethanol 95\%, safranin, dan hijau malaksit untuk analisis pewarnaan Gram dan spora. Sanitizer komersial yang meliputi MT Peroxy 404 $\mathrm{HC}{ }^{\circledR}$ (A; mengandung asam perasetat), MT Oxyquart $405 \AA$ (B; mengandung asam perasetat dan quat), Bioclean $510 \circledR(C$; mengandung asam perasetat, quat, air alkali dan hidrogen peroksida), MT Oxyquart 408® $(\mathrm{D}$; mengandung asam peasetat, quat, dan air alkali), Bioclean 500® (E; mengandung asam perasetat, air alkali, dan hidrogen peroksida, acidified peroxyacetic acid (F; mengandung asam perasetat dan air elektrolit), dan alkalized peroxyacetic acid (G; mengandung asam perasetat, air alkali, dan $\mathrm{NaCl}$ ).

Alat yang digunakan adalah peralatan gelas, mikroskop, pelat stainless steel (tipe 304, 1 x $1 \mathrm{~cm}$ ), inkubator $60{ }^{\circ} \mathrm{C}$ (Thermo Scientific Heraeus, Germany), inkubator $35{ }^{\circ} \mathrm{C}$ (Fisher), inkubator $30{ }^{\circ} \mathrm{C}$ (Fisher Scientific Isotemp), vortex (Genie 2 Scientific Industries), shaker (InnovaTM 2300, New Brunswick Scientific, New Jersey, USA), waterbath shaker (Polyscience), autoclave (ALP co.Ltd, Tokyo, Japan), timbangan analitik (Sartorius), dan refrigerator (Electrolux).

Penelitian ini terbagi menjadi 2 tahap. Tahap pertama adalah untuk memperoleh informasi mengenai sanitizer komersial berbasiskan asam perasetat yang mampu membunuh $B$. cereus pada konsentrasi yang direkomendasikan oleh produsen. Tahap kedua adalah mengevaluasi efektivitas sanitizer komersial terpilih terhadap biofilm $B$. cereus.

\section{Skrining Sanitizer Komersial yang Mampu Membunuh B. cereus}

Preparasi dan konfirmasi bakteri uji. Bakteri uji disegarkan pada media BHIB selama 24 jam di $37^{\circ} \mathrm{C}$ lalu digoreskan pada media agar miring TSA selama 24 jam di $37{ }^{\circ} \mathrm{C}$. Stok kerja disegarkan setiap minggu. Stok kerja disegarkan setiap minggu. Konfirmasi B. cereus dilakukan dengan metode pewarnaan Gram dan pewarnaan spora. Pewarnaan Gram dilakukan berdasarkan metode Becerra et al. (2016). Pewarnaan spora dilakukan berdasarkan metode pewarnaan Schaeffer Fulton (Oktari et al. 2017).

Preparasi sanitizer. Larutan stok sanitizer komersial dibuat pada konsentrasi $1 \%$ dengan dilarutkan pada akuades. 
Larutan stok selanjutnya dibuat dengan konsentrasi 200, 400 dan 800 ppm berdasarkan rekomendasi perusahaan sebagai stok kerja.

Uji kualitatif penghambatan sanitizer terhadap $B$. cereus. Kultur B. cereus ATCC 10876 berumur 24 jam (0.1 mL) diinokulasikan ke dalam media TSB (1 mL) sehingga jumlah awal B. cereus berkisar pada $8 \log \mathrm{CFU} /$ $\mathrm{mL}$. Sebanyak $1 \mathrm{~mL}$ sanitizer komersial ditambahkan sehingga diperoleh konsentrasi akhir sanitizer 200, 400, dan $800 \mathrm{ppm}$. Suspensi diinkubasi pada suhu $37^{\circ} \mathrm{C}$ selama 24 jam, $125 \mathrm{rpm}$. Setelah inkubasi, suspensi pada tabung yang tidak menunjukkan kekeruhan digores pada media padat TSA untuk melihat apakah B. cereus mampu membentuk koloni. Cawan diinkubasi pada suhu $37{ }^{\circ} \mathrm{C}$ selama 24 jam. Ada atau tidaknya kekeruhan pada TSB atau koloni pada TSA dinyatakan sebagai +++++ (ada pertumbuhan) atau - - - - - (tidak ada pertumbuhan).

\section{Pengaruh Sanitizer Komersial Asam Perasetat terhadap Biofilm B. cereus}

Pembentukan biofilm. Pembentukan biofilm pada permukaan pelat stainless steel (SS) mengacu pada Sinaga et al. (2016). Pelat SS steril diinkubasi dalam media 1/10 TSB yang juga diinokulasikan dengan $B$. cereus sedemikian rupa sehingga konsentrasi awalnya berkisar pada 5 log $\mathrm{CFU} / \mathrm{mL}$. Media berisi $B$. cereus dan pelat SS diinkubasi pada suhu kamar $\left(28^{\circ} \mathrm{C}\right)$ dengan agitasi $70 \mathrm{rpm}$, selama 48 jam. Densitas biofilm dihitung setelah membilas pelat SS dengan buffer $\mathrm{KH}_{2} \mathrm{PO}_{4}$ dan dilakukan swab dengan cotton swab kalsium alginat. Cotton swab dimasukkan ke dalam tabung reaksi yang berisi larutan fisiologis $(9 \mathrm{~mL})$ dan Na-heksametafosfat $0.1 \%(1 \mathrm{~mL})$. Setelah itu, suspensi diencerkan berseri dan dilakukan pemupukan pada cawan berisi media TSA. Cawan diinkubasi pada suhu $37{ }^{\circ} \mathrm{C}$ selama 48 jam dan densitas biofilm dinyatakan sebagai $\log \mathrm{CFU} / \mathrm{cm}^{2}$ (Dewanti dan Wong 1995). Densitas biofilm dihitung dengan menggunakan rumus sebagai berikut:

$$
\mathrm{N}=\frac{\sum C}{[(1 * n 1)+(0.1 * n 2) * d]} \times \frac{1}{\text { luas bidang diswab }}
$$

\section{Keterangan:}

$$
\begin{array}{ll}
\mathrm{N} & =\text { total densitas biofilm } \\
\mathrm{C} & =\text { jumlah seluruh koloni yang dihitung } \\
\mathrm{n} 1 & =\text { jumlah cawan pada pengenceran pertama } \\
\mathrm{n} 2 & =\text { jumlah cawan pada pengenceran kedua } \\
\mathrm{d} & =\text { pengenceran pertama/terkecil }
\end{array}
$$

Pemaparan sanitizer komersial terhadap biofilm $B$. cereus. Sanitizer komersial yang dalam tahap skrining secara kualitatif menunjukkan kemampuan inaktivasi terhadap bakteri $B$. cereus diuji lebih lanjut dengan tiga konsentrasi dan tiga waktu kontak (Ryu dan Beuchat 2005). Pelat yang telah mengandung biofilm dari tahap sebelumnya dipindahkan dan direndam dalam larutan sanitizer $\mathrm{B}$ atau $\mathrm{F}$ pada konsentrasi 200, 400, dan 800 ppm selama 1, 3, dan 5 menit. Pelat direndam dalam $10 \mathrm{~mL}$ letheen broth selama 2 menit untuk menetralkan aksi penghambatan dari sanitizer yang tersisa dan dibilas dengan $1 \mathrm{~mL}$ larutan fisiologis
$\mathrm{KH}_{2} \mathrm{PO}_{4}$, lalu dilakukan swab dengan cotton swab. Jumlah biofilm $B$. cereus pasca perlakuan sanitizer dihitung seperti di atas. Pengaruh sanitizer dalam menginaktivasi sel biofilm dinyatakan sebagai reduksi densitas biofilm dalam log CFU/ $\mathrm{cm} 2$, yang dihitung dengan mengurangi jumlah sel biofilm sebelum dengan jumlah setelah pemaparan dengan sanitizer

Scanning electron microscope (SEM). Pelat SS sebelum dan sesudah pemaparan sanitizer disiapkan untuk dianalisis struktur mikroskopinya. Pelat SS dibersihkan dengan merendam dalam larutan caccodylate buffer selama 2 jam $\left(4{ }^{\circ} \mathrm{C}\right)$, kemudian direndam dalam larutan glutaraldehyde $2.5 \%$ selama 2 hari. Pelat SS difiksasi menggunakan tannic acid 2\% selama beberapa hari dan dibilas dengan caccodylate buffer sebanyak 4 kali masing-masing 5 menit. Setelah dibilas menggunakan buffer, pelat SS didehidrasi menggunakan grade etanol $(50 \%, 70 \%, 85 \%$, dan 95\%) pada suhu ruang, dilanjutkan dengan dehidrasi menggunakan etanol absolut sebanyak 2 kali selama 10 menit. Pelat SS dikeringbekukan menggunakan freezed drier kemudian direkatkan pada specimens'stub dan dilapisi dengan $\mathrm{Au}$ menggunakan alat ion coater. Pengujian SEM dilakukan dengan perbesaran 1500-2000x.

\section{Analisis Data}

Penelitian ini menggunakan rancangan acak lengkap (RAL) dengan 3 faktor, yaitu paparan sanitizer, konsentrasi sanitizer (200, 400, dan 800 ppm), dan waktu kontak paparan (1, 3, dan 5 menit). Perlakuan dilakukan sebanyak dua kali ulangan. Data ditampilkan sebagai hasil rata-rata deviasi yang diolah menggunakan Microsoft Excel dan pengolahan statistika dilakukan menggunakan software IBM SPSS 25.0 dengan analisis ANOVA pada tingkat signifikansi $\alpha=0.05$. Hasil analisis digunakan untuk membandingkan signifikansi di antara data yang diperoleh.

\section{HASIL DAN PEMBAHASAN}

\section{Karakteristik Morfologi Kultur Bacillus cereus ATCC 10876}

Bacillus cereus ATCC 10876 yang digunakan dalam penelitian ini terlebih dahulu dikonfirmasi kemurniannya. Konfirmasi ini bertujuan untuk memastikan bahwa kultur yang akan digunakan tidak terkontaminasi oleh mikroorganisme lain. Uji konfirmasi yang dilakukan antara lain uji pewarnaan Gram dan pewarnaan spora. Hasil uji pewarnaan Gram, menunjukkan bahwa B. cereus ATCC 10876 merupakan Gram positif, berbentuk batang dan berantai (Gambar 1a). Pada uji pewarnaan spora sel tampak memiliki spora di tengah dengan warna hijau, dengan bentuk spora oval (ellipsoidal) dan tidak menggembung (Gambar 1b).

\section{Kemampuan Sanitizer Komersial dalam Menghambat dan Menginaktivasi $B$. cereus}

Screening dilakukan untuk memilih sanitizer yang akan digunakan pada analisis biofilm. Kemampuan menghambat sanitizer komersial terhadap $B$. cereus diamati setelah inkubasi 24 jam, $37{ }^{\circ} \mathrm{C}, 125 \mathrm{rpm}$. Tabung uji yang tidak keruh menunjukkan tidak adanya pertumbuhan koloni 

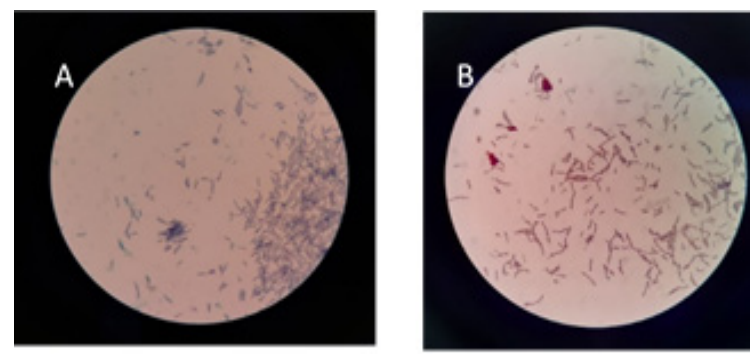

Gambar 1. a) Morfologi B. cereus ATCC 10876 pada perbesaran 1000x setelah pewarnaan Gram, b) morfologi B. cereus ATCC 10876 pada perbesaran 1000x setelah pewarnaan spora.

B. cereus yang mengindikasikan kemampuan sanitizer dalam menghambat bakteri tersebut. Ketujuh sanitizer menunjukkan tidak kekeruhan pada tabung uji, sehingga semua sanitizer diskrining lebih lanjut pada media TSA untuk melihat kemampuan inaktivasinya terhadap B. cereus.

Tabel 1 menunjukkan kemampuan recovery $B$. cereus pada media TSA setelah sebelumnya mengalami penghambatan dalam tabung berisi sanitizer komersial. Hasil inkubasi menunjukkan bahwa sanitizer A, C, D, E, dan $G$ mampu menginaktivasi pada konsentrasi 400 dan 800 ppm, tetapi pada kosentrasi 200 ppm masih ditemukan koloni bakteri pada cawan. Dua sanitizer yang menunjukkan efektivitas dalam inaktivasi bakteri $B$. cereus pada semua konsentrasi adalah sanitizer $\mathrm{B}$ dan $\mathrm{F}$.

Tabel 1. Koloni B. cereus dari tabung tanpa pertumbuhan pada media TSA setelah inkubasi 24 jam pada suhu $37^{\circ} \mathrm{C}$

\begin{tabular}{|c|c|c|c|c|}
\hline \multirow[t]{2}{*}{ No } & \multirow[t]{2}{*}{ Kode } & \multicolumn{3}{|c|}{$\begin{array}{l}\text { Densitas koloni yang tumbuh pada agar } \\
\text { cawan dari tabung yang diberi perlakuan } \\
\text { sanitizer }(\mathrm{ppm})\end{array}$} \\
\hline & & 200 & 400 & 800 \\
\hline 1 & A & +++++ & ---- & - - - - \\
\hline 2 & B & - - - - & - - - - & - - - - \\
\hline 3 & $\mathrm{C}$ & +++++ & ++++ & - - - - \\
\hline 4 & D & ++++- & - - - - & - - - - \\
\hline 5 & E & ++++- & - - - - & - - - - \\
\hline 6 & $\mathrm{~F}$ & - - - - & - - - - & - \\
\hline 7 & G & ++++- & $\ldots$ & $-\ldots$ \\
\hline
\end{tabular}

$*+++++=$ banyak pertumbuhan koloni, $++++-=$ agak banyak pertumbuhan koloni - - - - - = tidak ada pertumbuhan koloni

Sel vegetatif $B$. cereus sensitif terhadap senyawa asam perasetat (Kreske et al. 2006). Asam perasetat pada konsentrasi rendah memiliki kemampuan dalam mengontrol populasi mikroorganisme dalam spektrum luas, termasuk bakteri anaerobik dan pembentuk spora (Bajpai 2015). Sanitizer A yang mengandung senyawa tunggal asam perasetat, menunjukkan kemampuan menghambat pada semua titik konsentrasi, akan tetapi ketika digoreskan pada cawan TSA terlihat masih ada koloni yang tumbuh. Berdasarkan penelitian oleh Brinez et al. (2006) penggunaan sanitizer tunggal asam perasetat memiliki efektivitas lebih rendah terhadap inaktivasi bakteri dibandingkan dengan penggunaan sanitizer senyawa kombinasi. Sanitizer B terdiri dari senyawa kombinasi asam perasetat dan quat. Quaternary ammonium compound (QAC) atau quat merupakan senyawa yang memiliki aktivitas biosidal terhadap mikroba khususnya bakteri Gram positif (Stanga 2010). Quat memiliki efektivitas tinggi dalam mereduksi sel planktonik B. cereus (Peng et al. 2002). Penelitian lain oleh Araujo et al. (2013) juga menyatakan bahwa senyawa quat maupun kombinasinya terbukti mampu menginaktivasi $B$. cereus.

Kombinasi asam perasetat dan air elektrolit (asam) pada sanitizer $\mathrm{F}$ diduga menurunkan $\mathrm{pH}$ larutan. Kondisi ini menyebabkan banyaknya molekul asam yang tidak terdisosiasi sehingga dapat melakukan penetrasi pada membran dan masuk ke dalam sel bakteri. Kondisi $\mathrm{pH}$ sitoplasma sel yang tinggi menyebabkan molekul asam terdisosiasi sehingga molekul asam tidak lagi dapat melewati membran dan akhirnya menurunkan $\mathrm{pH}$ sitoplasma, yang seterusnya menginaktivasi sel bakteri (Mols dan Abee 2011).

\section{Pengaruh Konsentrasi dan Lama Perendaman Sanitizer Komersial B dan F terhadap Biofilm}

Gambar 2 menunjukkan jumlah reduksi biofilm $B$. cereus pasca diberi paparan sanitizer B atau F selama 1, 3 dan 5 menit. Penurunan jumlah biofilm setelah paparan sanitasisr B atau F dengan kontak waktu 1 menit ditampilkan pada Gambar 2a. Paparan sanitizer B menunjukkan reduksi biofilm tertinggi sebesar 58.24\% pada konsentrasi 200 ppm dan mengalami sedikit penurunan pada konsentrasi 400 dan 800 ppm. Sementara itu, paparan sanitizer F menunjukkan reduksi paling tinggi sebesar $19.36 \%$ pada konsentrasi 800 ppm. Secara keseluruhan, penggunaan sanitizer B pada waktu kontak 1 menit efektif $(\mathrm{p}<0.05)$ dalam menurunkan jumlah biofilm bila dibandingkan dengan penggunaan sanitizer $\mathrm{F}$.

Paparan sanitizer B atau F terhadap biofilm B. cereus juga dilakukan pada waktu kontak 3 menit (Gambar 2b). Paparan sanitizer B pada konsentrasi 200 ppm menunjukkan jumlah reduksi biofilm tertinggi yaitu $7267 \%$ bila dibandingkan dengan konsentrasi lainnya. Sementara itu, paparan sanitizer $\mathrm{F}$ menunjukkan jumlah reduksi tertinggi sebesar $49.35 \%$ pada konsentrasi 800 ppm. Penggunaan sanitizer B pada waktu kontak 3 menit efektif $(\mathrm{p}<0.05)$ dalam menurunkan jumlah biofilm bila dibandingkan dengan penggunaan sanitizer $\mathrm{F}$.

Gambar 2c menampilkan jumlah reduksi biofilm setelah paparan sanitizer B atau F selama 5 menit. Sanitizer $\mathrm{B}$ menunjukkan jumlah reduksi biofilm paling tinggi pada konsentrasi 200 ppm yaitu $80.58 \%$ dari jumlah awal 3.78 $\pm 0.43 \log \mathrm{CFU} / \mathrm{cm}^{2}$ bila dibandingkan dengan konsentrasi 400 dan 800 ppm. Hal serupa juga ditunjukkan oleh sanitizer F dengan jumlah reduksi sebesar $82.38 \%$ dari jumlah awal $3.25 \pm 0.26 \log \mathrm{CFU} / \mathrm{cm}^{2}$. Penggunaan konsentrasi berbeda pada analisis tidak menunjukkan perbedaan signifikan $(p>0.05)$ terhadap jumlah reduksi biofilm.

Berdasarkan hasil pengujian yang dilakukan, penggunaan sanitizer $\mathrm{B}$ dan $\mathrm{F}$ pada waktu kontak 1 dan 


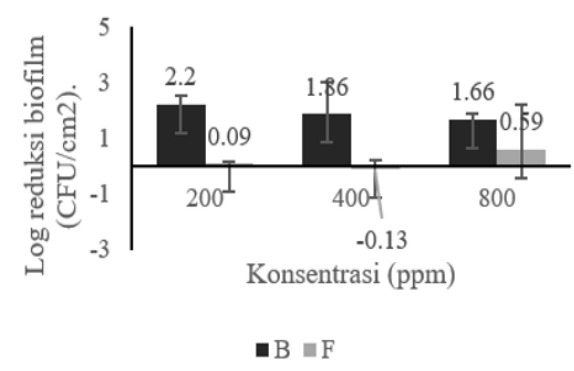

(a)

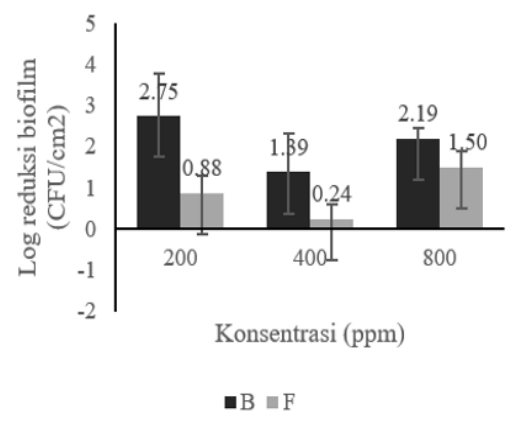

(b)

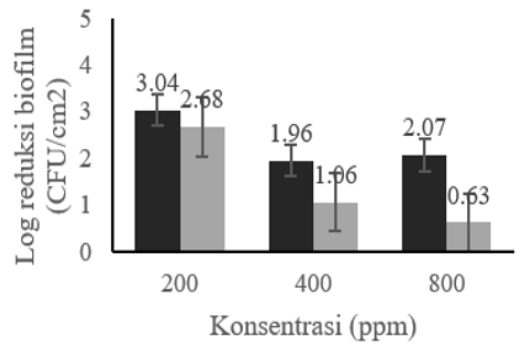

- $\mathrm{B}=\mathrm{F}$

(c)

Gambar 2. Inaktivasi biofilm B. cereus ATCC 10876 pada waktu (a) 1 menit, (b) 3 menit, dan (c) 5 menit

3 menit berpengaruh nyata $(\mathrm{p}<0.05)$ dalam mereduksi densitas biofilm B. cereus. Sanitizer B tersusun dari komponen senyawa asam perasetat dan quat. Kombinasi asam perasetat dan quat diduga memiliki efek sinergis terhadap inaktivasi biofilm. Quat merupakan surfaktan kationik yang banyak digunakan sebagai wetting agent, dan tergolong aman juga mudah diaplikasikan pada peralatan (Cramer 2006). Acidified peroxyacetic acid merupakan larutan asam perasetat yang pembuatannya dilakukan dengan menyesuaikan $\mathrm{pH}$, baik dengan penambahan asam organik maupun anorganik. Studi mengenai pengaruh acidified peroxyacetic acid terhadap populasi bakteri belum banyak dilakukan. Penelitian oleh Britton et al. (2020) menunjukkan bahwa acidified peroxyacetic acid efektif dalam menurunkan populasi E. coli dan tidak terdapat perbedaan yang signifikan antara perlakuan asam perasetat yang tidak diasamkan dengan yang diasamkan. Mekanisme inaktivasi bakteri oleh acidified peroxyacetic acid belum diketahui, namun diduga terdapat sinergitas antara mekanisme asam perasetat dan air elektrolit (asam) di dalamnya.

Peningkatan konsentrasi menunjukkan penurunan pada reduksi jumlah biofilm. Hal ini diduga karena hasil dekomposisi senyawa asam perasetat, yakni asam asetat. Asam asetat diketahui memiliki nilai $\mathrm{pKa}$ lebih rendah bila dibandingkan senyawa asam perasetat, sehingga jumlah asam yang tidak terdisosiasi menjadi lebih rendah dan tidak memberikan efektivitas lebih baik dalam menginaktivasi biofilm ketika konsentrasi ditingkatkan. Meskipun begitu, analisis terhadap perubahan $\mathrm{pH}$ maupun $\mathrm{pKa}$ dalam penerapan sanitizer masih perlu dilakukan di penelitian yang akan datang.

Menurut Environmental Protection Agency (2000) asam perasetat dalam bentuk larutan sanitizer pada umumnya mengandung konsentrasi yang rendah dan segera terdegradasi menjadi asam asetat, oksigen, dan air sehingga tidak memberi risiko toksikologi. Penggunaan konsentrasi 100-200 ppm asam perasetat direkomendasikan untuk peralatan yang kontak langsung dengan bahan pangan, sedangkan untuk peralatan pengolahan produk susu, konsentrasi yang direkomendasikan tidak melebihi 315 ppm.

\section{Analisis Morfologi Biofilm B. cereus ATCC 10876}

Gambar 3 menunjukkan morfologi dari biofilm $B$. cereus sebelum (a) dan pasca perlakuan sanitizer (b) pada permukaan pelat SS. Keberadaan matriks ekstraselular tampak pada pelat SS yang belum diberi paparan sanitizer, meskipun sebaran dan ketebalannya tidak merata. Biofilm pada pelat SS sebelum terpapar sanitizer terdiri dari sel tunggal dan agregat kecil. Beberapa sel tidak tampak utuh maupun berekatan satu sama lain serta jumlahnya tidak berlimpah. Hal ini dapat disebabkan oleh adanya sel yang terbuang ketika proses pembilasan saat preparasi. Paparan sanitizer menyebabkan perubahan pada struktur biofilm yang ditandai dengan rusaknya matriks ekstraselular sehingga tampak sangat sedikit bahkan hampir tidak tersisa. Jumlah sel biofilm pasca perlakuan sanitizer juga lebih sedikit bila dibandingkan dengan biofilm yang belum dipaparkan sanitizer.
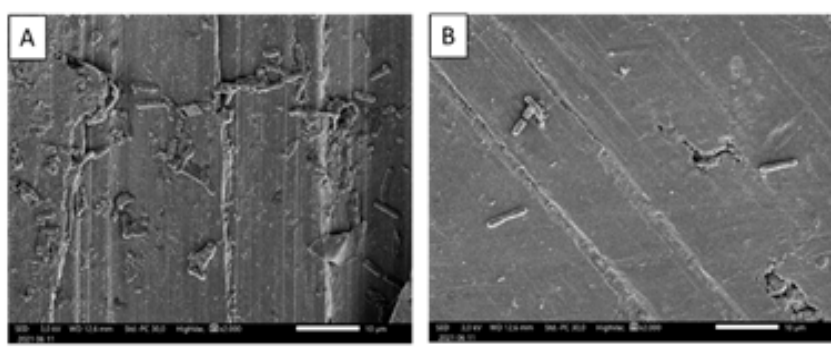

Gambar 3. Morfologi biofilm B. cereus ATCC 10876 yang diinkubasi 48 jam dalam 1/10 TSB. Pengamatan pada pelat SS sebelum paparan sanitizer (A) dan setelah paparan sanitizer (B); perbesaran 2000x, bar $=10 \mu \mathrm{m}$.

Pengamatan dengan Scanning Electron Microscopy menunjukkan bahwa densitas biofilm $B$. cereus pada pelat SS relatif rendah. Hal serupa juga ditemukan pada penelitian Lindsay et al. (2006) dan Wijman et al. (2007), dimana jumlah biofilm $B$. cereus yang dilaporkan sangat rendah. Biofilm Bacillus memiliki kemampuan melekat yang rendah dan rentan terhadap gaya gesekan. Pengamatan biofilm mono spesies (B. cereus) yang dilakukan oleh Faille et al. (2014) menunjukkan bahwa antara satu spesies dengan yang lainnya memiliki kemampuan berbeda dalam 
menghasilkan biofilm. Hal menarik yang juga ditemukan pada analisis biofilm antar strain Bacillus adalah semakin tebal biofilm justru semakin tidak kompak strukturnya.

Paparan sanitizer tampak mengurangi dan merusak struktur biofilm. Pada analisis morfologi, sanitizer B yang mengandung asam perasetat dan quat digunakan sebagai agen dalam inaktivasi biofilm. Sanitizer B dalam hal ini menyasar baik mono kultur maupun agrerat biofilm pada pelat SS, ditunjukkan dengan adanya kerusakan struktur matriks biofilm. Hal ini membutikan bahwa senyawa sanitizer dalam proses pembersihan dan sanitasi peralatan industri pangan sangat diperlukan, karena mampu mengurangi densitas biofilm dan mencegah potensi kontaminasi selama pengolahan.

\section{KESIMPULAN}

Dari 6 sanitizer komersial berbasiskan asam perasetat yang diuji, sanitizer komersial yang mengandung asam perasetat dan quat efektif (B) paling berpotensi digunakan dalam menghilangkan biofilm $B$. cereus pada pelat SS. Penggunaan sanitizer B dengan waktu kontak 5 menit pada konsentrasi 200 ppm menghasilkan inaktivasi tertinggi (3 $\mathrm{Log} / \mathrm{cm}^{2}$ ) terhadap biofilm B. cereus. Berdasarkan pengamatan melalui Scanning Electron Microscope, diduga bahwa paparan dengan sanitizer B yang mengandung asam perasetat dan quat menyebabkan kerusakan morfologi dan membunuh sel biofilm $B$. cereus.

\section{UCAPAN TERIMA KASIH}

Penelitian ini didanai oleh PT. Kevin Chemindo Anugerah, Indonesia dan didukung oleh fasilitas riset, serta teknis dari Laboratorium Karakterisasi Zoologi di Lembaga Ilmu Pengetahuan Indonesia.

\section{DAFTAR PUSTAKA}

Araujo, P.A., M. Lemos, F. Megulhao, L. Melo, \& M. Simoes. 2013. The influence of interfering substances on the antimicrobial activity of selected quaternary ammonium compounds. Int J Food Sci. 2013:1-9.

Bajpai, P. 2015. The control of microbiology problems. Pulp and Paper Industry. 2015:103-195.

Bang, H-J., S.Y. Park, S.E. Kim, M.M.F. Rahaman, \& S-D. Ha. 2017. Synergistic effects of combined ultrasound and peroxyacetic acid treatments against Cronobacter sakazakii biofilms on fresh cucumber. J Food Sci Technol. 84(2017):91-98.

Branda, S-S., J.E. Gonzales-Pastor, S. BenYehuda, R. Losick, \& R. Kolter. 2001. Fruting body formation by Bacillus subtilis. Proceeding of National Academy of Sciences of the United Stated of America. 98(20):11621- 11626.

\section{Becerra SC, DC Roy, CJ Sanchez, RJ Christy, DM}

Burmeister. 2016. An optimized staining technique for the detection of Gram positive and Gram negative bacteria within tissue. BioMed Central. 9: 216. doi: 10.1186/s13104-016-1902-0
Brinez, W.J., A.X. Rois-Sagues, M.H. Herrero, T. LpoezPedemonte, \& B. Guamis. 2006. Bactericidal efficacy of peracetic acid in combination with hydrogen peroxide against pathogenic and non pathogenic strains of Staphylococcus spp., Listeria spp., and Escherichia coli. Food Control. 17(2006):516-521.

Britton, B.C., I. Geornaras, J.O. Reagan, S. Mixon, D.R. Woerner, \& K.E. Belk. 2020. Antimicrobial efficacy of acidified peroxyacetic acid treatments against surrogates for enteric pathogens on prerigor beef. Meat and Muscle Biology. 4(1):30, 1-7.

CDC. 2008. Guideline for Disinfection and Sterilization in Healthcare Facilities. https:/www.cdc.gov/ infectioncontrol/guidelines/disinfection/disinfectionmethods/chemical.html [14 Juli 2021].

Chang, H-J., J-H. Lee, B-R. Han, T-K. Kwak, \& J. Kim. 2011. Prevalence of the levels of Bacillus cereus in fried rice dishes and its exposure assessment from Chinese restaurants. Food Sci Biotechnol. 20 (5): 1351-1359.

Chino, T., Y. Nukui, Y. Morishita, \& K. Moriya. 2017. Morphological bacterial fast-acting effects of peracetic acid, a high-level disinfectant, against Staphylococcus aureus and Pseudomonas aeruginosa biofilms in tubing. Antimicrob Resist Infect Control. 6:122.

Cramer, M.M. 2006. Food Plant Sanitation: Design, Maintenance, and Good Manufacturing Practices. Taylor and Francis Group, LLC, USA.

Dewanti, R., \& A.C.L. Wong. 1995. Infuence of culture condition on biofilm formation by Escherichia coli O157:H7. International Journal of Food Microbiology. 26(1995):147-164.

EPA (Environmental Protection Agency). 2000. 40 CFR Part 180 about Peroxyacetic acid: Exenmption from the requirement of a tolerance.

Faille, C., T. Bénézech, G. Midelet-Bourdin, Y. Lequette, M. Clarisse, G. Ronse, A. Ronse, \& C. Slomianny. 2014. Sporulation of Bacillus spp. within biofilms: A potential source of contamination in food processing environments. Food Microbiology. 40(2014): 64-74.

Fogele, B., R. Granta, O. Valpica, \& A. Berzins. 2017. Occurrence and diversity of Bacillus cereus and moulds in spices and herbs. Food Control. 83(2018):69-74.

Huang, Z., Y. Lin, F. Ren, S. Song, \& H. Guo. 2019. Benzalkonium bromide is effective in removing Bacillus cereus biofilm on stainless steel when combined with cleaning-in-place. Food Control. 105(2019):13-20.

Kim, H., M.J. Moon, C.Y. Kim, \& K. Ryu. 2019. Efficacy of Chemical sanitaizers against Bacillus cereus on food contact surfaces with scratch and biofilm. Food Sci Biotechnol. 28(2):581-590.

Kreske, A.C., J-H. Ryu, \& L.R. Beuchat. 2006. Evaluation of chlorine, chlorine dioxide, and a peroxyacetic acidbased sanitizer for effectiveness in killing Bacillus cereus and Bacillus thuringiensis spores in suspension, on the surface of stainless steel, and on apple. J Food Prot. 9(8):1892-1903.

Kumari, S., \& P.K. Sarkar. 2016. Bacillus cereus hazard and control in industrial dairy processing environment. Food Control. 69(2016):20-29. 
Lee, S-H., G.V. Barancelli, C.H. Corassinn, R.E. Rosim, C.F.S.C. Coppa, \& C.A.F. Oliveira. 2017. Effect of peracetic acid on biofilms formed by Listeria Monocytogenes strains isolated from a barazillian cheese processing plant. Brazillian Journal of Pharmaceutical Sciences. 53(3):1-7.

Lindsay, D. V.S. Brozel, \& A. von Holy. 2006. Biofilmspore response in Bacillus cereus and Bacillus subtilis during Nutrient Limitation. J Food Protect. 69(5): 1168-1172.

Mols, M., \& T. Abee. 2011. Bacillus cereus responses to acid stress. Environmental Microbiology. 13(11):28352843.

Oktari, A., Y. Supriatin, M. Kamal, \& H. Syafrullah. 2017. The bacterial endospore stain on schaeffer fulton using variation on methylene blue solution. Journal of Physics: Conference Series. Series 812(2017).

Peng, J.S., WC. Tsai, \& C-H. Chou. 2002. Inactivation and removal of Bacillus cereus by sanitizer and detergent. Int J Food Microbiol. 77(2002):11-18.

Ryu, J.H., \& L.R. Beuchat. 2005. Biofilm formation and sporulation by Bacillus cereus on stainless steel surface and subsequent resistance of vegetative cells and spores to chlorine, chlorine dioxide, and a peroxyacetic acidbased sanitizer. J Food Protect. 68(12):2614-2622.
Sinaga, Y.M.R., R. Dewanti-Hariyadi, \& Suliantari. 2016. Cronobacter sakazakii memasuki kondisi viable but non culturable selama pembentukan biofilm. Jurnal Teknologi dan Industri Pangan. 27(2):140-147.

Stanga, M. 2010. Sanitation: Cleaning and Disinfection In the Food Industry. Wiley-VCH GmbH\&Co, KGaA, Weinheim.

Visvalingam, J., \& R-A. Holley. 2017. Evaluation of chlorine dioxide, acidified sodium chlorite and peroxyacetic acid for control of Escherichia coli O157:H7 in beef patties from treated beef trim. Food Res Int. 103(2018):295- 300.

Voort, M., \& T. Abee. 2013. Sporulation environment of emetic toxin-producting Bacillus cereus determines spore size, heat resistance and germination capacity. J Appl Microbiol. 114(4):1202-1210.

Wijman, J.G.E., P.P.L.A. Leeuw, R. Moezelaar, MH. Zwietering, \& T. Abee. 2007. Air-liquid interface biofilms of Bacillus cereus: formation, sporulation, and dispersion. Appl Environ Microbiol. 73(5):1481-1488. 